\title{
A HELYI GAZDASÁG SZEREPLŐINEK EGYÜTTMÜKÖDÉSI LEHETŐSÉGEI A VIDÉKI TÉRSÉGEK VERSENYKÉPESSÉGÉNEK FOKOZÁSÁRA ${ }^{\mathbf{1}}$ POSSIBLE COOPERATIONS OF PLAYERS OF LOCAL ECONOMY TO BOOST THE COMPETITIVENESS OF RURAL AREA
}

\author{
Nagy Henrietta \\ egyetemi docens \\ Szent István Egyetem, Gazdaság és Társadalomtudományi Kar \\ E-mail: nagy.henrietta@gtk.szie.hu
}

\section{Összefoglalás}

A tanulmány célja annak feltérképezése, hogy a vidéki - a magyarországi helyzetet alapul véve legtöbbször hátrányos helyzetü - térségek esetében a helyi szereplök milyen módon tudnak részt venni a térségek komplex felzárkóztatásában a vidékbiztonság kilenc pillérét figyelembe véve. Természetesen nem létezik olyan egységes stratégiai út, sablon, mely mindegyik térségre alkalmazható lenne, hiszen más módon és más körülményeknek köszönhetően jutottak el a gazdasági-társadalmi tekintetben hátrányos helyzetbe ahonnan ki kell törniük, de mégis vannak olyan kulcsfontosságú tényezők, melyek fejlesztése elengedhetetlen ahhoz, hogy ebböl a helyzetből ki tudjanak emelkedni és a vidéki jelző ne legyen egyenlő automatikusan a hátrányos helyzettel. Hazánkban a lakosság jelentős hányada él vidéken, tehát a vidéki térségek felzárkóztatása, versenyképességének fokozása megkérdőjelezhetetlen prioritás kell, hogy legyen nemzeti szinten.

\begin{abstract}
The aim of this study is to discover the ways how the local players can play a role in the complex development of rural - based on the Hungarian situation mainly disadvantaged - areas taking the 9 pillars of the rural security. Obviously, there is no such uniform strategic path or sample that could be applied for all the areas, since they got to the socio-economically disadvantaged situation in individual ways and due to various conditions. However, there are key factors whose development is inevitable to break out from this unfavourable status so that rurality would not be automatically equal to unfavourable situation. In Hungary, a lot of people live in the countryside, thus helping the rural areas to catch up and to improve their competitiveness should be an unquestionable priority at national level.
\end{abstract}

Kulcsszavak: helyi gazdaságfejlesztés, versenyképesség, helyi szereplők, vidékfejlesztés JEL besorolás: R10, R58

LCC: HD 72-88

\section{Bevezetés}

A térségek - köztük a vidéki térségek - leghatékonyabb fejlesztését felülröl lefelé, illetve alulról felfelé irányuló fejlesztések kombinációjaként kell elképzelni. Azaz szükséges jól átgondolt, az ország területi sajátosságait figyelembe vevő nemzeti szintü stratégiák megfogalmazása és alkalmazása (egy stratégia/szakpolitika nem elegendő, hiszen a komplex fejlesztések a gazdaság, a társadalom és a környezet számos területét érintik), valamint ehhez igazodó, a

\footnotetext{
${ }^{1}$ A tanulmány a KÖFOP-2.1.2-VEKOP-15-2016-00001 számú, a „A jó kormányzást megalapozó közszolgálatfejlesztés" című projekt keretében készült.
} 
keretrendszerbe beleillő, de a helyi viszonyokat, feltételeket szem előtt tartó helyi kezdeményezések rendszere. Utóbbi esetében a rendszeren nagy hangsúly van, hiszen egymáshoz nem illeszkedő, a lehetséges multiplikátor hatásokat nem kiaknázó, egymással párhuzamosan, de egymástól függetlenül müködő, egymáshoz nem kapcsolódó fejlesztések nem feltétlenül hozzák meg a várt pozitív hatást és elmozdulást a térségben, így ezek erőforráspazarlást, nem hatékony együttmüködéseket eredményezhetnek, melyek sok esetben nem jelentenek motivációt a helyi szereplök aktív és elkötelezett részvételére. Mivel nincs egységes megoldási séma a területi különbségek mérséklésére, így fontos a hátrányos helyzet kialakulásának ismerete, elemzése, ami nem nélkülözheti a természeti és a gazdasági tényezők mellett a társadalmi folyamatok részletes vizsgálatát (Káposzta, 2014).

Ha a vidéki térségek felzárkóztatásáról, valamint versenyképességük fokozásáról van szó, jelenleg hazánkban a Nemzeti Vidékstratégia számít a legátfogóbb országos szintü keretrendszernek. A Stratégia célja, hogy 2020-ig a vidék társadalmi és gazdasági folyamataiban látható és minden érintett számára érezhető javulás következzen be. Megalkotásával és végrehajtásával a cél a vidéki Magyarország egészének megújítása. Ennek érdekében négy átfogó területről; az agrárgazdaságról, a vidékfejlesztésről, az élelmiszergazdaságról valamint a környezet védelméről határoz meg tennivalókat.

A Stratégia az eddig követett agár- és vidékpolitikákhoz képest megközelítésében is újszerü. Újszerü, mert integrált vidékfejlesztési politikát tüz ki célul, mert a családi gazdaságok fejlesztésének ad elsőbbséget, és mert a monokultúrás tömegtermelés helyett a minőségi, mozaikos, a környezet- és tájgazdálkodási szempontokat szem előtt tartó mezőgazdaságot részesíti előnyben. A dokumentumban alapcélkitüzésként szerepel a tájak épségének tudatos megőrzése, a lakosság jó minőségü és biztonságos élelmiszerrel történő ellátása, a természeti erőforrásokkal való fenntartható gazdálkodás, az ivóvízbázisok, a talajok, az élővilág és a környezet védelme (http://videkstrategia.kormany.hu/).

\section{A helyi gazdaságfejlesztés és a vidékbiztonság kapcsolata}

A helyi gazdaságfejlesztés minden helyi szereplö érdeke és felelőssége is egyben, beleértve a helyi vállalkozásokat, a helyi lakosságot, a helyi önkormányzatot és a civileket is. A helyi gazdaságfejlesztésre általában a világban, de különösen a fejlődö országokban úgy tekintenek, mint az életminőség javítására, munkanélküliség, szegénység és egyenlőtlenség megszüntetésére alkalmazható megoldás. Ezek alapján tehát mind a szereplők oldaláról nézve, mind a céljait/feladatait tekintve egy átfogó kérdéskört takar, amiből egyértelmüen következik, hogy az egyes szereplők részéről szoros együttműködést szükségeltet.

Viszonylag új kutatási és szakpolitikai terület, így a tervezés folyamatai és a megvalósítás számos formában megmutatkozik és sokféle alternatív elméleteket és megközelítéseket hordoz magában. Megfelelő gazdaságpolitikákkal, a helyi gazdaság fejlesztését ösztönözve számos gazdasági probléma orvosolható a humán és pénzügyi tőke kedvezőbb áramlásának megteremtésével (Reich, 1991). Új munkahelyek teremtése illetve a humán erőforrás fejlesztése nem könnyü feladat. Mind a helyi intézményeknek, mind a nemzeti szintü politikáknak oly módon kell felsorakoztatni a helyi humán és egyéb erőforrásokat, hogy mind a regionális mind a globális piacok igényeinek megfeleljenek, az új munkahelyek létesítésénél pedig arra törekednek, hogy mind a helyi társadalomhoz, mind a helyi feltételekhez illeszkedjenek (Blakely és Bradshaw, 2002). 
Dinamikus helyi szintű fejlődés elérése érdekében integrált szemléletet kell alkalmazni, mely kiterjed gazdasági, társadalmi, jóléti, környezeti és politikai tényezőkre. Rogerson (2009) szerint átfogó stratégiát kell kidolgozni minden térségre a fejlődés elérése érdekében.

Az 1035/2012. (II. 21.) Kormány határozatban elfogadott Nemzeti Biztonsági Stratégiát alapul véve a vidékbiztonság 9 pillére (politikai-kormányzati; fizikai; gazdasági; szociális-társadalmi; környezeti-környezetvédelmi; élelmiszer-élelmezés; infrastruktúra; fenntarthatóság és megújulás; vidékbiztonsági öngondoskodás) között is a fent említett tényezők szerepelnek, hiszen a biztonság nem csupán közbiztonsági kérdésekre vonatkozik, hanem számos olyan tényezőre, feltételre, melyek figyelembe vételével biztonságosabbá, versenyképessé, minden szempontból élhetővé tehetők a vidéki térségek. Ennek elérése érdekében számos szakpolitika összehangolt müködése szükséges, melyek alkalmazása végrehajtási és proaktív módon is a helyi szereplők kiemelt felelőssége is, hiszen a helyi adottságokat, a bevonható helyi szereplöket, a lokális potenciált és ezek alapján az elvégzendő feladatokat ők ismerik a leginkább. (Szilágyi-Boldizsár, 2016)

A bevezetésben részletezett Nemzeti Vidékstratégia és a Nemzeti Biztonsági Stratégia számos azonos terület/ágazat fejlesztését célozza. Mindkét stratégia komplex, integrált fejlesztést támogat és ösztönöz a vidéki térségek élhetőbbé tételére bár némileg más-más eszközökkel és prioritásokkal. A végcél mindkettőnél azonos: a vidéken élők életminőségének javítása, a lakosság vidéken tartása azzal, hogy gazdasági-társadalmi-környezeti szempontból fenntartható, a lokális és globális piacon egyaránt versenyképes szereplőkké válnak.

\section{A helyi gazdaságfejlesztésben rejlö lehetőségek}

A hagyományos értelemben vett gazdaságpolitikákkal szemben a helyi gazdaságfejlesztés számos előnyt hordoz magában. Rodrigues-Pose (2001) szerint a helyi gazdaságfejlesztés ösztönzi és biztosítja a helyi szereplök részvételét, azaz a helyi lakosság aktívan közremüködhet saját jövője megtervezésében. A helyi gazdaságfejlesztés azt is biztosítja, hogy a helyi vállalkozások szerepet vállaljanak a folyamatban és nyitottabbá váljanak a helyi közösségekkel való szorosabb együttmüködésre.

Mivel a helyi gazdaságfejlesztés - nevéből adódóan - a lokalitásra, az endogén erőforrásokra épít és a komparatív előnyök kihasználására törekszik, ezért a hely gazdaságok számára rugalmasságot biztosít, hozzájárul a helyi munkahelyek és lehetőségek megteremtéséhez. Ezeknek köszönhetően javítja a vidéki élet minőségét. Természetesen a munkahelyteremtés, a helyi szereplők aktív részvétele, a minőségi változásra való törekvés csak akkor valósul meg, ha általában az ott élők és az ott müködő vállalkozások biztonságban érzik magukat, tehát az általános biztonságérzet megfelelőnek tekinthető.

Azonban a helyi gazdaságfejlesztésben résztvevők szerepe és felelőssége megkérdőjelezhetetlenül komoly, hiszen nekik kell kijelölni a rövid-, közép- és hosszútávú célokat, helyesen megválasztani a prioritásokat, a megvalósítás eszközeit, valamint a résztvevőket. Az Európai Unió szubszidiaritás alapelvén alapulva a helyi gazdaságfejlesztés a lehetőségek tárháza, de egyben jelentős kockázatokat is magában hordozó kezdeményezés is lehet.

Számos esetben egyetlen elkötelezett, a helyi viszonyokat jól ismerő személy (polgármester, helyi vállalkozó, egy civilszervezet tagja vagy akár egy helyi lakos) elegendő ahhoz, hogy elinduljanak a helyi életminőség javulását eredményező fejlesztések, de ugyanúgy egy személyen is múlhat az is, ha mind ezek elmaradnak egy térségben. A humán erőforrás - 
véleményem szerint - a legfontosabb tényező a helyi gazdaságfejlesztés tervezési és megvalósítási folyamatában.

Ezt mi sem bizonyítja jobban, mint hogy az európai uniós források jelentős része nem a kedvezőtlen humán erőforrással bíró vidéki térségekben került felhasználásra, ahol a leginkább szükség lett volna a fejlesztésekre, a felzárkóztatásra - ami még messze nem a versenyképesség fokozását jelenti - hanem a képzett humán erőforrással bíró vállalkozásokat tömörítő középmagyarországi régióban.

\section{Anyag és Módszertan}

A fentiekben részletezett szakirodalmi háttérre alapozva, a humán erőforrás vizsgálatára fókuszálva gyüjtöttem adatokat az Eurostat adatbázisából a magyar régiókra. A számos kapcsolódó adatok közül azokat válogattam ki és mutatom be, melyek - véleményem szerint a humán erőforrás kifejezetten alacsony voltát hangsúlyozzák.

\section{Eredmények}

\section{A helyi gazdaságfejlesztés potenciális szereplöi a magyar régiókban}

Ha megvizsgáljuk a magyarországi régiók humán erőforrás helyzetét, meglehetősen kedvezőtlen képpel szembesülünk. Az 1. sz. ábra azt mutatja, hogy a 18-24 év közötti korosztály hány \%-a nem fejezi be az iskolát. Ez az adat világos képet tud arról adni, hogy a fiatal társadalom mekkora hányada nem rendelkezik semmilyen végzettséggel, azaz sem a munkaerőpiacon, sem a helyi gazdaság fejlesztése során nem lehet rájuk számítani. Ha megnézzük az ábrát az rajzolódik ki, hogy az uniós csatlakozásunk óta ez az arány a magyar régiókban stagnál, de leginkább növekszik, különösen az észak-magyarországi régióban ahol 2016-ra már megközelítette a 20\%-ot. Ez azt jelenti, hogy minden ötödik 18-24 év közötti fiatalra igaz, hogy kimarad az iskolából, nem szerez még alapfokú végzettséget sem. Ez a folyamatosan emelkedő tendencia olyan helyzetet fog teremteni az elkövetkezendö években nemcsak az említett régióban -, amely jelentősen megterheli a szociális hálót, illetve növelheti a bünözési statisztikákat - országosan, nem csak az adott régióban.

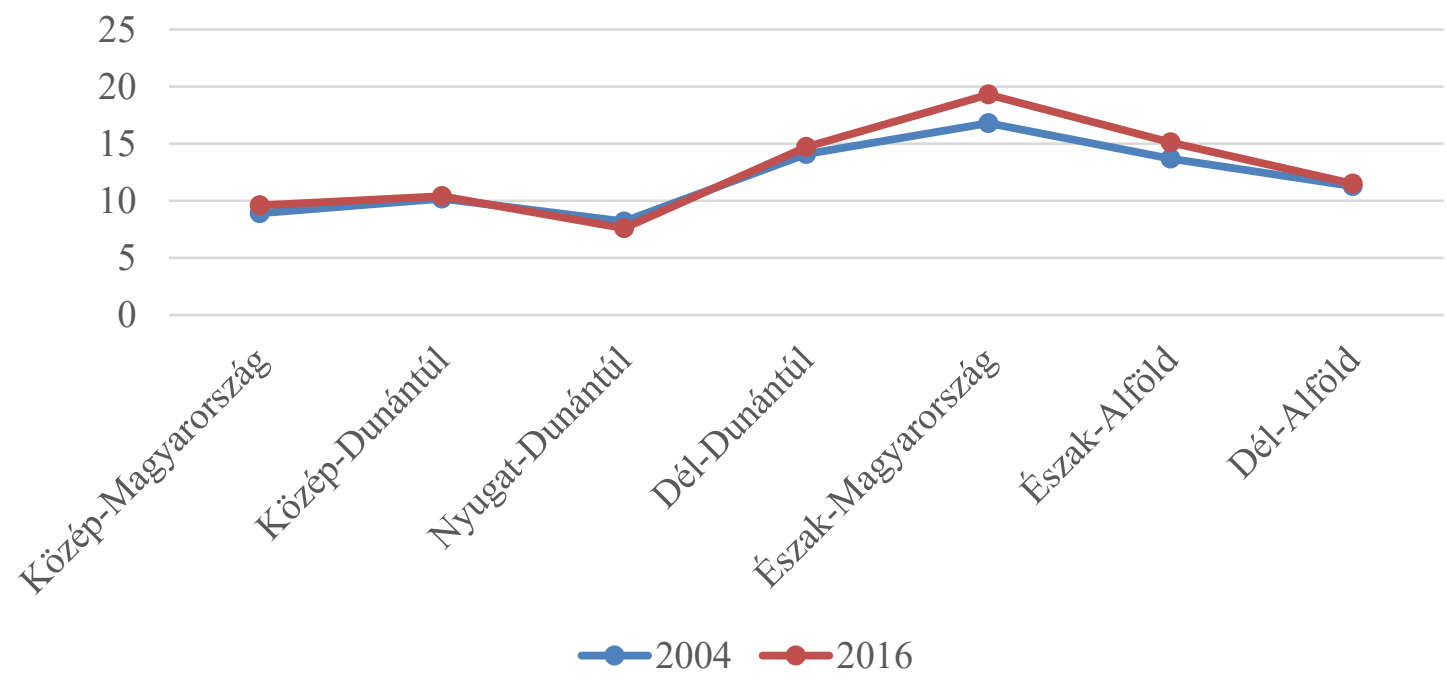

1. sz. ábra. Az iskolából kimaradó fiatalok aránya a 18-24 éves korosztályban (\%) Forrás: Eurostat, 2017. 
Képzettség hiányában a munkaerőpiacon ezek a fiatalok nem tudnak megjelenni a kínálati oldalon, sem a vállalkozások, sem az önkormányzatok nem szívesen foglalkoztatják őket. Egy adott térség versenyképességének fokozásához azonban képzett munkaerőre van szükség, így azon vidéki települések, ahol ez a tendencia egyre jellemzőbb, nemcsak rövid, de hosszútávon is számos kihívással kell, hogy szembe nézzenek, hiszen a humán erőforrás fejlesztése, a lakosság képzettségi szintjének emelése rövidtávon nem megvalósítható, valamint hatásait közép-és hosszútávon érezteti.

A vidéki térségek gazdaságfejlesztését célzó intézkedéseknek azt is figyelembe kell venni, hogy még mindig jelentős azon fiatalok aránya, akik sem (hivatalos) alkalmazásban nem állnak, sem oktatásban nem vesznek részt. A 15-24 év közötti fiatalokra vonatkozó kedvezőtlen statisztika az észak-magyarországi, a két alföldi és a dél-dunántúli régióban a legszembetünőbb, és az ábrán bemutatott 12 évnyi időtartam változásai is azt bizonyítják, hogy jelenős javulás csak közép- ill. hosszútávon érhető el de csak célirányos fejlesztési programokkal.

A probléma itt is ugyanaz, mint az 1. sz. ábrán bemutatott helyzettel, miszerint a jelenlegi - kor alapján a legaktívabbnak tekinthető - humán erőforrás fejlesztése csak jelentős források bevonásával lehetséges, és az még mindig csak az alapfokú képzettségi szintre történő fejlesztést jelenti, nem pedig a meglévő tudásra alapozott további tudás megszerzését, amely a versenyképesség fokozásához elengedhetetlen.

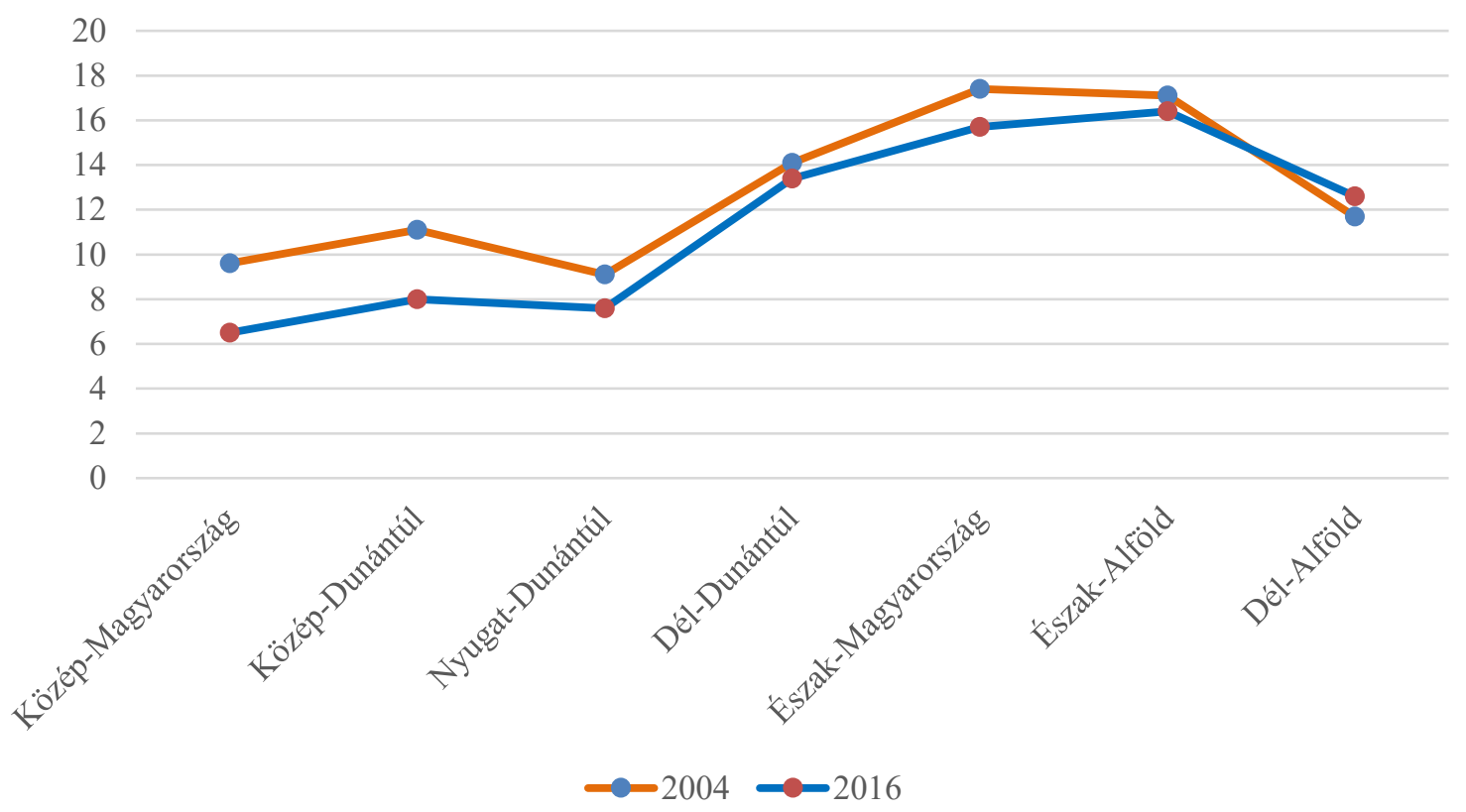

\section{2. sz. ábra. 15-24 év közötti fiatalok közül azok aránya, akik nem tanulnak és nem is} dolgoznak (\%)

Forrás: Eurostat, 2017.

A fentiekben részletezett kedvezőtlen tendenciák mellett azonban meg kell jegyezni, hogy az aktív, 25-64 év közötti lakosságon belül egyre nő azok aránya, akik felsőfokú végzettséggel rendelkeznek, ami jó alapot jelenthet az alulról jövő kezdeményezések megvalósítása során, de messze nem elegendő a sikerhez. A 3. sz. ábrán jól látható az a jelentős területi különbség, mely hazánkban tapasztalható és amely indokolhatja a közép-magyarországi régió forrásmegkötésben betöltött kiemelkedő szerepét. Azt azért mindenképpen érdemes hangsúlyozni, hogy számos esetben a szakemberhiány, a szakmunkáshiány jelenti a nagyobb problémát, nem pedig a diplomások hiánya. 


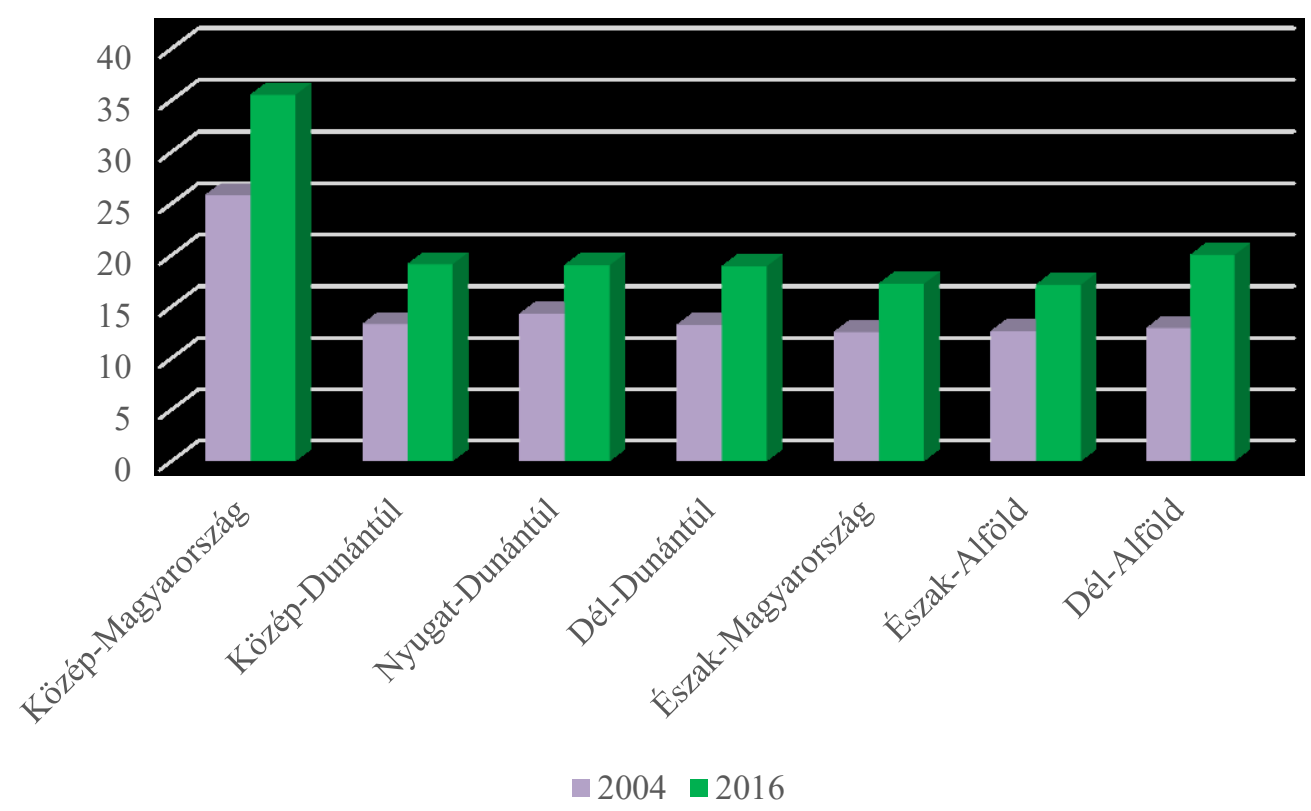

3. sz. ábra. A felsőfokú végzettségüek aránya a 25-64 éves korosztályban (\%) Forrás: Eurostat, 2017.

\section{Szerepvállalások és lehetséges együttmüködések a helyi gazdaságfejlesztésben}

Számos szakirodalom a helyi önkormányzatoknak tulajdonítja a helyi gazdaságfejlesztés koordináló és irányító szerepét, tőlük várják a kezdeményezést és a fejlesztési elképzeléseket, ám a rájuk delegált feladatok, a korlátozott finanszírozási lehetőségeik, a közigazgatásra szakosodott és nem stratégiai fejlesztésben gyakorlott szakemberekből álló humán erőforrás, valamint üzleti jellegü szakmai indokok is azt predesztinálják, hogy nem feltétlenük minden esetben az önkormányzatoktól kell várni az egyedüli megoldást. A központi szabályozás és a területi közremüködők sokszínü helyi gazdaságfejlesztési részvételi módja országonként ugyan eltérő funkcióhoz juttatja a helyi önkormányzatokat, de összességében a kelet-közép-európai országokban a helyi önkormányzatok még mindig biztos szereplői a helyi gazdaságfejlesztési kezdeményezéseknek. A volt szocialista országokban, ahol a liberalizációs, a privatizációs, a globalizációs és a külföldi tőke beáramlási folyamatokkal szinte egyszerre kellett szembenéznie a piaci szereplőknek, kiemelkedő pozícióba kerültek a szabályozási hátteret alakító és az intézményrendszerbe beépülő helyi önkormányzatok (Young és Kaczmarek, 2000). Rajtuk kívül azonban még sok helyi közremüködő vesz részt a beavatkozásokban.

A lehetséges közbenjárók köre térségenként eltérhet, hiszen az függ a településrendszertől, a közigazgatási rendszertől és annak finanszírozásától, a társadalmi szerveződések hagyományától, a vállalkozásfejlesztésre létrehozott intézményrendszertől, a bankrendszertől, az oktatási rendszertől, az érdekvédelmi szervezetek erejétől és számos más tényezőtől.

A hangsúly nem az egyes közremüködőkön van, hanem sokkal inkább az általuk létrehozott együttműködéseken, illetve a résztvevők közötti horizontális és vertikális kapcsolatokon (Cameron et al. 2000). Az együttmüködések terén azonban a térség országai még kevés tapasztalatot tudnak felmutatni, hiszen csak most tanulják a partnerségépítés fortélyait (Puljiz 2004; Espon 2006). Társadalmi jellemző továbbá az alacsony részvételi hajlandóság is, amely a rendszerváltó országok állampolgárainak kiábrándultságával és a közösségi ügyektől való távolmaradásával hozható összefüggésbe (Plostajner és Mendes 2004). Ebben a helyzetben van komoly feladata a helyi önkormányzatoknak, akik célja, hogy ösztönözzék és fenntartsák a 
vállalkozások aktivitását a településen. A Nemzetközi Munkaügyi Szervezet (International Labour Organization, 2006) szerint a helyi gazdaságok feladata megoldások és alternatívák keresése a helyi versenyképesség javítására és a komparatív elönyök megerösítésére ahhoz, hogy a globális térben is versenyezni tudjon. Ez utóbbi kiemelt fontosságú, hiszen a versenyképesség és annak fejlődése a globális tér visszajelzései alapján értelmezendő még akkor is, ha a végső cél a helyben élők életminőségének javítása.

Trousdale (2005) szerint a helyi gazdaságfejlesztés megvalósításának sikere 6 kulcstényezőn múlik, melyek az alábbiak:

- Helyi vezetés a helyi önkormányzatnál, helyi vállalkozásoknál, valamint a helyi közösségekben.

- Egy olyan gazdaság környezet, mely mindenki számára biztosít lehetőségeket.

- A helyi fiatalság bevonása fiatalok fejlesztési programjaiba.

- Munkahelyteremtési lehetőségek fenntartható munkahelyek létrehozására.

- Jó kormányzás.

- Elérhető kapacitások és képességek a helyi gazdaság minden szintjén.

Blakely és Bradshaw (2002) szerint az önkormányzatok dönthetnek úgy, hogy fejlesztőként, vagy vállalkozóként, koordinátorként, vezetőként vagy akár motiválóként vesz rész a folyamatokban.

Az eddigi tapasztalatok azt mutatják, hogy elsősorban kínálatorientált stratégiát alkalmaznak, azaz alapvető céljuk a befektetők vonzása és csak másodlagos a helyi KKV-k vagy a helyi humán erőforrás fejlesztése. Az endogén megközelítés elterjedésével azonban arra lehet számítani, hogy a helyi erőforrások felértékelődnek és a lokális feltételekre alapozott fejlesztések kerülnek előtérbe.

Az önkormányzatok mellett jelentős szerepet kell vállalnia a helyi vállalkozóknak, vállalkozásoknak is, hiszen ők azok akik arra törekednek, hogy - amennyiben rendelkezésre áll megfelelő képzettségü munkaerő - helyi humán erőforrást alkalmazzanak, ezzel jövedelemhez juttassák a helyi lakosságot, akik a jövedelmüket elsősorban helyben kívánják elkölteni. Ezáltal a helyi vállalkozások, leginkább KKV-k hosszútávú fennmaradása is biztosított. A vállalkozások lehetnek azok a szereplök, akik meghatározhatják a humán erőforrás fejlesztés irányát, a munkaerőigényük, a szakmák iránti igényük megfogalmazásával, mely kijelölheti az irányt az oktatási és képzőintézmények fejlesztésére egyaránt.

\section{Következtetések}

A helyi gazdaságfejlesztéssel, annak jelentőségével, a lokalitásban rejlő lehetőségekkel és ugyanakkor kihívásokkal is már számos tudományos publikáció foglalkozott, számos alulról felfelé irányuló fejlesztési program tüzte ki céljául, de sikertörténetekről sokszor a helyi szereplök közötti kooperáció hiánya miatt nem beszélhetünk.

Sokak számára kézenfekvő, hogy a sikeres fejlesztéseknek helyi szinten kell indulniuk és a fejlesztési ötleteknek a helyiek igényein és a helyi erőforrásokon kell alapulniuk, és a megvalósításban elsősorban a helyiek részvételére számítanak. Elméleti síkon ez müködhet, de a gyakorlatban számos tényező befolyásolja sikerességét, hiszen az egyes esetek egyedi erőforrás-kombinációra építkeznek. A nemzetközi és hazai trendeket, valamint az uniós fejlesztéspolitikákat és forrásokat figyelembe véve nem kérdés, hogy a területi különbségek mérséklésének, a hátrányos helyzetü vidéki térségek felzárkóztatásának és a vidék élhetőbbé tételének legfontosabb eszköze az endogén erőforrásokra alapozott helyi fejlesztés. Ha a 
vidékbiztonság főbb prioritásait is figyelembe vesszük, akkor egyértelmü, hogy a lokális fejlesztéseknek nem kizárólag gazdasági jellegü célokat kell szolgálniuk, hanem kiemelt figyelmet kell kapjon a társadalom fejlesztése, a környezet megóvása, az élelmiszerbiztonság, valamint az infrastruktúrafejlesztés is, melyek együttes fejlesztéseként javulhat a vidék népességmegtartó képessége versenyképes vidéki környezetben.

\section{Köszönetnyilvánítás}

A tanulmány a KÖFOP-2.1.2-VEKOP-15-2016-00001 számú, a „A jó kormányzást megalapozó közszolgálat-fejlesztés” címü projekt keretében készült.

\section{Irodalomjegyzék}

1. Blakely, E.J. - Bradshaw, T.K. (2002): Planning local economic development: Theory and practice. 3rd edition. California. Sage Publications.

2. Cameron, G. - Danson, M. - Halkier, H. (2000): Institutional Change, Governance and Regional Development: Problems and Perspectives. 266-275. p. in: Danson, M. et al. (eds.) Governance, Institutional Change and Regional Development. Hampshire, Ashgate, Aldershot.

3. Espon (2006) Espon 2.3.2.: Governance of territorial and urban policies from EU to local level. http://www.espon.eu/mmp/online/website/content/projects/243/374/file_2186/draft_f r-2.3.2-full.pdf

4. Eurostat, http://ec.europa.eu/eurostat/data/database

5. International Labour Organization (ILO). 2006. A Local Economic Development Manual for China, ILO, Geneva

6. Káposzta. J. (2014): Területi különbségek kialakulásának föbb összefüggései, Gazdálkodás, 5. sz.

7. Meyer, D.F: Local Economic Development (LED), Challenges and Solutions: The Case of the Northern Free State Region, South Africa Mediterranean Journal of Social $\begin{array}{lllll}\text { Sciences, } & \text { Vol } & 5 & \text { No } & \text { 16, }\end{array}$ http://www.mcser.org/journal/index.php/mjss/article/viewFile/3346/3300

8. Nemzeti Biztonsági $\quad$ Stratégia. 2014.kormany.hu/download/f/49/70000/1035_2012_korm_hatarozat.pd

9. Nemzeti Vidékstratégia. http://videkstrategia.kormany.hu/

10. Plotajner, Z. - Mendes, I. (2004): Citizens Participation. - How to Improve Development on Local Level? 97-113. p in: Handbook with Best Practice Examples from South-East Europe. Friedrich Ebert Stiftung, Zagreb.

11. Puljiz, J. (2004): Economic Development. How to Improve Development on Local Level? 9-24. p in: Handbook with Best Practice Examples from South-East Europe. Friedrich Ebert Stiftung, Zagreb.

12. Reich, R. (1991): The work of nations. New York. Vintage.

13. Rodrigues-Pose, A. (2001): The role of ILO in implementing local economic development strategies in a globalized world. London School of Economics. Unpublished paper.

14. Rogerson, C.M. (2009): Strategic Review of local economic development in South Africa. Final report submitted to Minister S Shiceka of Department of Development Planning and Local Government (DPLG). Commissioned by DPLG and GTZ.

15. Szilágyi T., Boldizsár G.: (2016) A biztonságos vidék, mint az állam létfeltétele PRO SCIENTIA RURALIS 1:(4) pp. 24-34. 
16. Trousdale, W. 2005. Promoting Local Economic Development through strategic Planning: The local Economic Development Series, Volumes 1 to 5. Nairobi. Kenya. UN-Habitat

17. Young, C. - Kaczmarek, S. (2000): Local government, local economic development and quality of life in Poland. GeoJournal 2-3. 225-234. p. 